\title{
A Modified Technology Acceptance Model to Analyze the Usage of Internet-Based Education Tool in Primary Schools in Libya
}

\author{
Mohamed Abugharsa ${ }^{1}$, Gulsah Hancerliogullari Koksalmis ${ }^{2}$, Umit Tokeser ${ }^{3}$ \\ ${ }^{1}$ Department of Computer Science, Institute of Materials and Engineering, Kastamonu University \\ ${ }^{2}$ Department of Industrial Engineering, Faculty of Management, Istanbul Technical University, Istanbul, Turkey 34367 \\ ${ }^{3}$ Department of Mathematics, Faculty of Science and letters, Kastamonu University
}

Correspondence Author: Mohamed Abugharsa, Department of Computer Science, Institute of Materials and Engineering, Kastamonu University

E-mail: Anesareen1976@gmail.com

Received date: 11 December 2018, Accepted date: 22 Janaury 2018, Online date: 29 January 2019

Copyright: (C) 2019 Mohamed Abugharsa et al, This is an open-access article distributed under the terms of the Creative Commons Attribution License, which permits unrestricted use, distribution, and reproduction in any medium, provided the original author and source are credited.

\begin{abstract}
This paper intends to determine the factors influencing the utilization of web-based learning system as a tool to improve and support learning process in Libyan school's classrooms. However, as many researchers have claimed that insertion of technologies in learning process must be proceeded by the user acceptance, without this effort the strategy of inclusion technologies in schools would be heavily underutilized and ultimately would fail. For that reason, a model has been produced by extending the technology acceptance model (TAM), in which four external variables, which are computer anxiety, perceived enjoyment, computer playfulness, and gender have been added to the basic TAM model. An online survey was launched to collect the data from 250 teachers, educational experts and workers in the education sector in Libya to cover the range of opinions from the different regions in Libya. The main aim of this study is to extend the Technology Acceptance Model (TAM) to determine the factors that affect the usage of a web-based learning system as learning and teaching tools in Libyan primary schools. The result of this study has revealed that behavioral intention has a significant positive direct effect to predict the actual use of webbased learning system. Moreover, perceived usefulness, perceived ease of use, computer playfulness, perceived enjoyment and attitude toward use are found to be indirect significant determinants of actual use of web-based learning system. On the other hand, computer anxiety is found to have indirect insignificant effect on actual use of web-based learning system. In terms of gender, females' actual use of web-based learning system is higher than males'; however, it is not significant.
\end{abstract}

Key words: Web-based learning, Technology Acceptance Model, perceived usefulness, perceived ease of use, computer anxiety, perceived enjoyment, computer playfulness, and gender.

\section{INTRODUCTION}

The education sector has benefited from the improvement made in information technology and communication technology (ICT); as a result, the educational institutions have focused more on the integration of ICT in the educational environment, which has led to improve the quality of learning (Chang \& Wang, 2008). The integration of ICT in learning process will offer the learners with a more creative environment and enable them to be more confident when using technology (van-Braak, 2001), while reducing the limitations of location and time (Al-Zaidiyeen, Mei, \& Fook, 2008; Alzamil, 2006). In addition, in the last two decades ICT has undergone considerable development and, as a result, has greatly improved. At the same time, teachers have considered ways of integrating the use of computers into their classroom practice while researchers have implemented numerous research projects concerning the use of ICT-based tasks. These include knowledge hunts, Webquests, online communication and so forth.

E-learning is defined as an innovative technique that offer a creative learning method to facilitate the learning in corporative environment to anyone, in anywhere, at any times. This can be achieved by using elements of different digital technologies with other types of educational materials (Khan, 2005).

Web-based learning system is broadly utilized as a learning technique in these days. Fundamentally it is a technique for improving the learning process by utilizing hypermedia and HTML. Moreover, web-based learning system can enhance the traditional education process by several ways. On-location learning is the basic method for educating in which learners utilize 
conventional classrooms or data centers for self-study as another way to learn and access information, web-based learning system has numerous, preferences as learning material can be reached by the clients. Even students or teachers do not need to go to schools or universities, or to the place where the learning materials are found; users of web-based learning system can supplement their exercises and lessons with wide database (Alessi\&Trollip, 2001). On the other hand, despite the mentioned benefits, several educators still hesitate to use web-based learning system. In fact, this is called technology resistance and, in many cases, it leads to system failure, and the technologies remain abandoned or heavily underutilized once supplied to the school.

In the literature, for the purpose of analyzing the user's behavioral intention to use information technology(IT), the Theory of Reasoned Action (TRA) was integrated in psychology research and then the theory is adopted to use in IT field. Having improved the TRA, the researchers developed and introduced the Technology Acceptance Model (TAM) (Davis, Bagozzi, and Warshaw ,1989). TRA is usually used to investigate the human behavioral intention (Fishbein and Ajzen, 1975), which is affected by the attitude toward use and the subjective norm (Davis, 1989; Liaw, and Huang 2009). By adopting TRA theory, Davis (1989) developed the Technology Acceptance Model to examine the acceptance of IT by the end users. Over the previous decade, TAM model has been used by specialists to investigate the acceptance of IT, by predicting the user perceptions of perceived usefulness and perceived ease of use which are the main factors that TAM model uses (Lee, Kozar, Larsen, 2003).

In the literature many studies have been done related to web-based learning focusing on the acceptance and usage of webbased learning by students and teachers (Abbad, Moris \& Nahlik, 2009; Cho, Cheng \& Hung, 2009; Raaij \& Shepers, 2008; Saade, Nebebe, \& Tan, 2007; Cheng, Lou, Shih \& Kuo, 2013; Yuen \& Ma, 2008; Al-alak \& Alnaws, 2011; Altawallbeh, Thiam, Alshourah \& Fong, 2015, Elkaseh, Wong, and Fung, 2015).

This study aims to examine the actual use of web-based learning systems of teachers and workers in education sector by utilizing the TAM. The contributions of this are twofold. First, our study is focusing on Libyan primary schools. To the best of our knowledge, no scientific research has yet observed the factors affecting actual use of web-based learning system in Libyan primary schools from teachers' and other workers' perspective. Second, behavioral intention is found to have a direct significant effect on actual use of web-based learning system. Perceived usefulness, perceived ease of use, computer playfulness, perceived enjoyment and attitude toward use are found to be indirect significant determinants of actual use of web-based learning system. Moreover, the result has shown no significant effect of gender on behavioral intention to use web-based learning system.

The organization of the rest of the paper is as follows. In the next section, we review the theoretical background and provide hypotheses. This is followed by research model and methodology. Then, the results of the analysis are presented. The paper concludes with a discussion of the findings and suggestions for future research.

\section{THEORETICAL BACKGROUND AND HYPOTHESES DEVELOPMENT}

The aim of this study is to investigate the factors affecting the usage of web-based learning system in Libyan primary schools. The research model of this study utilizes the basic TAM model which consists of perceived ease of use, perceived usefulness, attitude toward use, behavioral intention to use, and actual use and includes external variables which are perceived enjoyment, computer anxiety, computer playfulness, and gender. The proposed model has 9 constructs and 13 hypotheses, which is provided in Fig. 1.

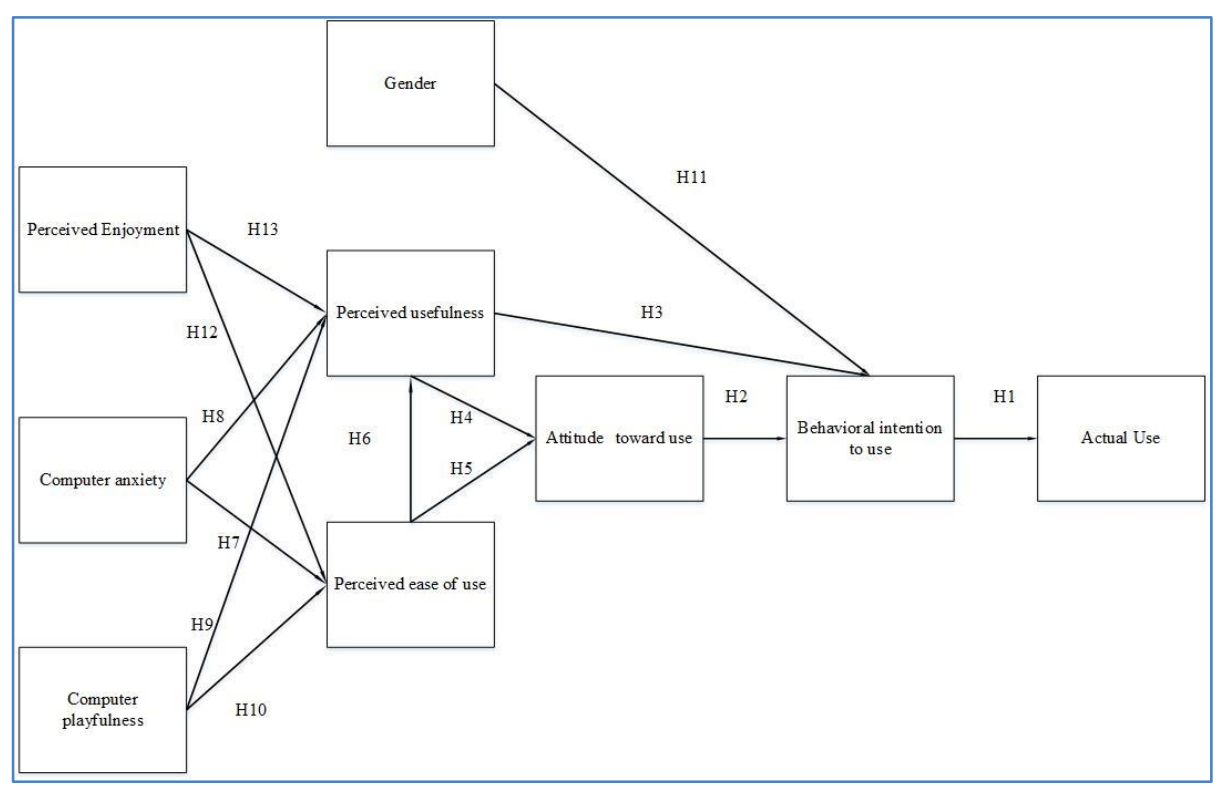

Figure 1 Proposed research model

\subsection{Actual use}

The two approaches that can be used to measure the actual usage (AU) of particular system are objective and subjective methods, however objectives forms are generally conducted for registers of the usage of the system itself (S. Dasgupta, M. Granger, N. McGarry, 2002). On the other hand, subjective forms of system usage are conducted from the user opinion for 
Citation: Mohamed Abugharsa, et al., A Modified Technology Acceptance Model to Analyze the Usage of Internet-Based Education Tool in Primary Schools in Libya. Australian Journal of Basic and Applied Sciences, 13(1): 28-43. DOI: 10.22587/ajbas.2019.13.1.5

example, by self-reported or using questionnaires. According to TAM, behavioral intention to use is the main factors influencing the actual use of particular system (Davis, 1989).

\subsection{Behavioral Intention to Use}

The Behavioral intention to use (BI) is thought to be a prompt predecessor of use and gives a sign around a people's status to accomplish out a particular conduct., "the stronger the intention to engage in a behavior, the more likely should be its performance" (Ajzen, 1981). Many studies have been revealed that BI has a significant effect on actual use AU (Davis et al., 1989; Taylor and Todd, 1995; Taylor and Todd, 1995; Venkatesh and Davis, 2000; Venkatesh et al., 2003).

H1: Behavioral intention toward Use has a positive effect on actual use of Web-based Learning system.

\subsection{Attitude toward Use}

Attitude toward (ATU) use is defined as a person who trusts that carrying out a specific activity will prompt good results (Ajzen and Fishbein, 1980). In TAM the attitude toward use determine the behavioral intention to use system(F.D.Davis,1989). Furthermore, many studies have explained the positive effecting of attitude toward use on behavioral intention (Agarwal \& Karahanna, 2000; Venkatesh \& Morris, 2000).

H2: Attitude toward Use of web-based learning system will have a positive effect on behavioral intention to use of Web-based Learning.

\subsection{Perceived Usefulness}

The definition of Perceived Usefulness (PU) is that "the degree to which a person believes that using a particular system would enhance his/her job performance" (Davis, 1989), Several studies have been done to point the significant effect of PU on Predicting BI (Gagné, 2008; Amoako-Gyampah, 2007; Liaw, 2008; Saadé and Galloway, 2005; Snchez-Franco et al., 2009; Liu et al., 2005; Landry et al., 2006; Liu et al., 2010; Rodriguez and Lozano, 2011; Šumak et al. ,2011)

In literature many studies have been done to investigate the effecting PU on the individual ' attitude toward use technology (S. Y. Stop, 2009; M. K. Lee, C. M. Cheung, and Z. Chen, 2005; M. Lee, 2010; Liu et al., 2009; Saad and Galloway, 2005).

H3: Perceived usefulness will have a positive effect on behavioral intention to use Web-based Learning.

H4: Perceived usefulness will have a positive effect on attitude toward use of Web-based Learning.

\subsection{Perceived Ease of Use}

The definition of Perceived ease of use PEOU is that, to what extent the individual believes utilizing a specific framework or system would be free of exertion (David, 1989). Many studies revealed, the influence of PEOU on attitude toward use of the system (Adams, Nelson, \& Todd, 1992; Pedersen \& Nysveen, 2003; Saadé \& Kira, 2007) (S. Y. Stop, 2009; M. K. Lee, C. M. Cheung, and Z. Chen, 2005; M. Lee, 2010; Liu et al., 2009; Saad and Galloway, 2005). Furthermore, studies shown PEOU has positive effect on PU (J.C.Lin and H. Lu, 2000).

H5: Perceived ease of use will have a positive effect on attitude toward use of Web-based Learning.

H6: Perceived ease of use will have a positive effect on Perceived usefulness of Web-based Learning.

\subsection{Computer Playfulness}

When a person deals naturally with the Computer and feel spontaneous that refer to playfulness (J. Webster, 1989). Moon and Kim have revealed that, perceived playfulness has significant effect on perceived usefulness; Bruner and Kumar (2005) have come out with the result there is a positive relationship between playfulness and perceived ease of use.

H7: Computer Playfulness will have a positive effect on Perceived ease of use to use of Web-based Learning.

H8: Computer Playfulness will have a positive effect on Perceived usefulness to use of Web-based Learning.

\subsection{Perceived Enjoyment}

Perceived enjoyment (EN) can be defined as the quantity to which the activity of the use of innovation is gave the impression to be fun (Davis et al., 1992). Many research have shown the influence of Enjoyment on Perceived Ease of Use. (Venkatesh, 2000; Huang, et al, 2004). in addition, studies have revealed that Enjoyment inspired usefulness through ease of use, without assessing its direct effect on usefulness (Venkatesh, 2000).

H9: Perceived Enjoyment will have a positive effect on Perceived usefulness of Web-based Learning.

H10: Perceived Enjoyment will have a positive effect on Perceived ease of use to use Web-based Learning.

\subsection{Gender}

Many studies have examined the distinction among gender perceptions in the acceptance of eLearning (Arenas-Gaitan et al., 2010; Gonzalez-Gomez et al., 2011; Raman, 2011; Zhou and Xu, 2007; Okazaki \& Santos, 2012). Some of these studies revealed that there are differences among males had females in acceptance of systems. a few studies have found out no large differences among men and women of their perceptions the acceptance of eLearning, for instance, Furthermore, another study found that both male and female students showed same interest to adopt E-studying as a supplementary device (AlHarbi, 2010).According the study of Taiwanese workers, which show gender has impact on behavioral intention to use e-learning (BI) (ONG, C.S. y LAI, J.Y, 2006).

H11: Gender toward Use will have a positive effect on behavioral intention to use of Web-based Learning. 


\subsection{Computer Anxiety}

Computer anxiety is defined as a person's apprehension, fear, or negative emotion in actual or expected interplay with computers (Heinssen et al., 1987; Venkatesh \& Morris, 2000). In literature numerous studies revealed that, Computer anxiety become determinants of PEUS (Gefen, Karahanna, \& Straub,2003a, 2003b; Gefen \& Straub, 1997; Pedersen \& Nysveen, 2003). In addition, many studies have shown negative impact of computer anxiety on perceived usefulness (Gilroy FD and Desai HB, 1986; Igbaria M and Chakrabarti A ,1990; Morrow PC, Prell ER and McElroy JC ,1986).

H12: Computer anxiety will have a negative effect on Perceived ease of use to use of Web-based Learning.

H13: Computer anxiety will have a negative effect on Perceived usefulness of use Web-based Learning.

\section{METHODOLOGY}

\subsection{Survey design}

This study used a quantitative approach, with data collected through the use of an online survey. The survey was divided into two parts, with the first part dealing with the demographic variables and the second part consisting of questionnaires related to constructs' items. The participants were non-English speakers and the items were translated into the Arabic language. Therefore, to make sure the questionnaires were understood by the participants, a a demonstration of how to fill out the questionnaire was given to ensure that there has been no uncertainty in understanding the questions and that the respondents will fill in the survey correctly, leading to collection of real responses.

In addition, to ensure that the participants understood the concept of filling in and submitting this survey, a presentation was done by the author in some Libyan schools. Additionally, the respondents were given enough time to go through the items and were given any information that they needed.

\subsection{Data collection}

The total number respondents were 290, where men made up $43.44 \%$, and women made up $56.56 \%$ of respondents. As this study focuses only on primary schools, only the responses which came from primary schools have been used, and the respondents who answered that they do not use the Internet in their classes were dropped. The remaining responses amounted to 254 , as shown in Table 1.

Table1 Demographic profile

\begin{tabular}{|c|c|c|c|c|c|}
\hline Gender & $\begin{array}{l}\text { Male } 123 \\
48.42 \%\end{array}$ & $\begin{array}{c}\text { Female } 131 \\
51.58 \%\end{array}$ & & & \\
\hline Age & Min: 23 & Max: 54 & Average: 36.88 & & \\
\hline Education Level & $\begin{array}{l}\text { High School degree } \\
45\end{array}$ & $\begin{array}{l}\text { Associate Degree } \\
41\end{array}$ & $\begin{array}{c}\text { Undergraduate } \\
136\end{array}$ & $\begin{array}{l}\text { Graduate } \\
\quad 32\end{array}$ & \\
\hline Job description & $\begin{array}{c}\text { Teacher } \\
237\end{array}$ & $\begin{array}{c}\text { School Manager } \\
3\end{array}$ & $\begin{array}{c}\text { Education } \\
\text { Specialist } \\
06 \\
\end{array}$ & $\begin{array}{l}\text { Instructor } \\
01\end{array}$ & $\begin{array}{c}\text { Administrative } \\
\text { staff } \\
07 \\
\end{array}$ \\
\hline You are working in & $\begin{array}{c}\text { Primary schools } \\
254 \\
\text { Middle Institute } \\
--\end{array}$ & $\begin{array}{c}\text { Secondary schools } \\
-- \\
\text { High institute } \\
--\end{array}$ & $\begin{array}{c}\text { High schools } \\
-- \\
\text { College } \\
--\end{array}$ & $\begin{array}{c}\text { University } \\
-- \\
\text { None of } \\
\text { these } \\
--\end{array}$ & \\
\hline $\begin{array}{l}\text { Working years in } \\
\text { Education sector }\end{array}$ & $\begin{array}{c}\text { Less than } 1 \text { year } \\
09\end{array}$ & $\begin{array}{l}1-2 \text { years } \\
15\end{array}$ & $\begin{array}{c}2-5 \text { years } \\
39\end{array}$ & $\begin{array}{c}5-10 \text { years } \\
62 \\
\end{array}$ & $\begin{array}{c}\text { More than } 10 \text { years } \\
129\end{array}$ \\
\hline $\begin{array}{c}\text { Computer } \\
\text { Experience }\end{array}$ & $\begin{array}{c}\text { None } \\
03\end{array}$ & $\begin{array}{c}1-2 \text { Years } \\
57\end{array}$ & $\begin{array}{c}3 \text { - } 5 \text { Years } \\
55\end{array}$ & $\begin{array}{c}6-10 \text { Years } \\
64\end{array}$ & $\begin{array}{l}\text { More than } 10 \text { years } \\
75\end{array}$ \\
\hline $\begin{array}{c}\text { Weekly Computer } \\
\text { use }\end{array}$ & $\begin{array}{c}\text { None } \\
05\end{array}$ & $\begin{array}{c}1-10 \text { hours } \\
193\end{array}$ & $\begin{array}{l}\text { More than } 10 \text { hours } \\
56\end{array}$ & & \\
\hline Internet Experience & $\begin{array}{c}\text { None } \\
1 \\
\text { More than } 5 \text { years: } \\
135\end{array}$ & $\begin{array}{c}\text { Less than } 6 \text { months: } \\
06\end{array}$ & $\begin{array}{c}6 \text { months - } 1 \text { years: } \\
8\end{array}$ & $\begin{array}{c}1-2 \text { years } \\
39\end{array}$ & $\begin{array}{c}2-5 \text { years } \\
65\end{array}$ \\
\hline
\end{tabular}

\subsection{Measurement development}

The survey utilized a Likert type scale, ranging from (1) strongly disagree to (5) strongly agree, however, in term of actual use this construct was measure by three items (AU1, AU2, AU3) which were originally taken from (Ngai et al. ,2007) and Venkatesh and Davis ,1996). The construct Behavioral intention to use was measured by three items (BI1, BI2, BI3) were taken from Cheong \& Park, 2005.

Liao and Lu, 2008. Attitude toward use was measured by three items (ATU1, ATU2, ATU3) the resource was (Taylor \& Todd, 1995). Perceived ease of use was measured by five items (PEOU1, PEOU2, PEOU3, PEOU4, PEOU5) were taken from (Davis, 1989 \& Roca et al., 2008 \& Venkatesh 2000). Perceived usefulness was measured by four items (PU1, PU2, PU3, PU4) 
were taken from the source (Roca et al., 2008 \& Venkatesh 2000). Computer playfulness was measured by three items (CP1, CP2, CP3) were taken originally from (Venkatesh and Bala, 2008; Lee et al. ,2009). Perceived enjoyment was measured by three items (EN1, EN2, EN3) were taken from (Moon and Kim, 2001). Finally, computer anxiety was measured by three items (ANX1, ANX2, ANX3) were taken from (Moon and Kim, 2001) see table 2.

Table 2 constructs' items

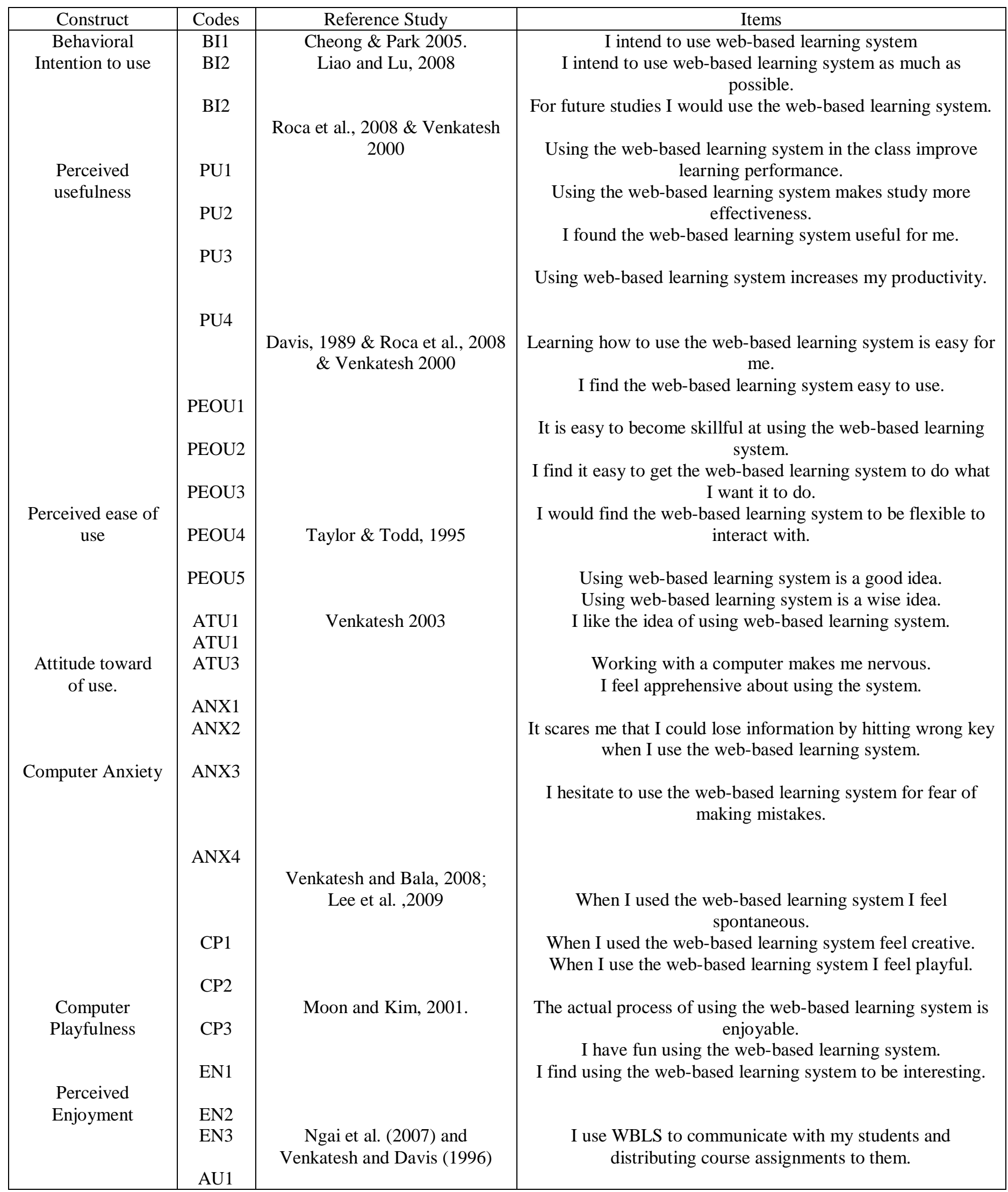


Citation: Mohamed Abugharsa, et al., A Modified Technology Acceptance Model to Analyze the Usage of Internet-Based Education Tool in Primary Schools in Libya. Australian Journal of Basic and Applied Sciences, 13(1): 28-43. DOI: 10.22587/ajbas.2019.13.1.5

\begin{tabular}{|c|c|c|c|}
\hline Actual Use & AU2 & & $\begin{array}{c}\text { I use WBLS to distribute course materials and grades to my } \\
\text { students. }\end{array}$ \\
& AU3 & I allow my students to discuss the course with one another \\
through WBLS.
\end{tabular}

\subsection{Data Analysis}

In our study, we used the structural equation model to validate our theoretical research model and by using partial least squares (PLS) Smartpls software Version 3.2.7 (Joseph F et.al, 2017) as analysis tools. One of the advantages of using PLS is that we could avoid a few of the restrictive assumptions underlying covariance-based SEM techniques along with multivariate normality and huge sample length (Fornell \& Bookstein, 1982; Falk and Miller, 1992).

\section{RESULTS}

A two- step approach was done in this study. The first step is the measurement model and the second step are the structural model.

\subsection{Measurement Model}

A partial least squares SEM PLS path model consists of two types of analysis. In the first phase, a structural model is created which explains the relationships (paths) between the constructs in the model to examine the research' hypotheses. In the second phase, the measurement models of the constructs that display the relationships between the constructs and the indicator variables are analyzed, along with those which examine the validity, and reliability of the model (Joseph F Hair, 2017).

Eight variables, consisting of 28 items, define our measurements model: actual use (AU), behavioral intention to use (BI). Attitude to use (ATU), perceived ease of use (PEOU), perceived usefulness (PU), perceived enjoyment (EN), computer anxiety(ANX), and computer playfulness $(\mathrm{CP})$.

The first stage is to run the measurement model, and analyze the data using smartpls. The measurement model examining by two phases, the first phase is convergent reliability which, individual item reliability, composite reliability, and average variance extracted (AVE). Second phase is discriminant validity which, examine the cross loading and variable correlation (root square of AVE) (Joseph F Hair, 2017). Finally, the Discriminant Validity According to the criteria we used, its equal to the square of the average variance extracted for each construct (AVE) (Fornell-Larcker standard, 1981).

The results of measurement model of this study are displayed in Table 3. In terms of convergent validity, the results showed that, the reflective measures were above the threshold. In particular, all Average Variance Extracted AVE values exceeded 0.5 and ranged from 0.572 to 0.882 . In terms of constructs, the Cronbach's alpha's values ranged from 0.777 to 0.932 , which indicated high internal reliability that all the values are above the threshold, which is 0.7 . While the Composite reliability of the constructs exceeded the criterial level, which is 0.7 , by ranging from 0.869 to 0.7 in the main stream. The results show that the outer loading (Factor loading) values exceeded the threshold 0.7, except for two items were under the threshold value, which in our case did not affect the overall value of our measurements. In the second part of the measurement model, which is discriminant validity, the discriminant validity of our model showed that the variable correlation of construct (the root square of AVE) should be higher than the correlation of the construct and the other constructs in the model which shown by Correlation matrix in Table 4;Therefor, in this matrix the diagonal values equal of the root square of AVE for every construct, which exceeded the rest of the value in the same row, therefore, the matrix showed acceptable discriminant validity.

Table3. The measurement model.

\begin{tabular}{|c|c|c|c|c|c|c|}
\hline Construct & Codes & $\begin{array}{c}\text { Factor } \\
\text { loading }\end{array}$ & t-value & $\begin{array}{c}\text { Average Variance } \\
\text { Extracted (AVE) }\end{array}$ & $\begin{array}{c}\text { Composite } \\
\text { Reliability CR }\end{array}$ & \multirow{2}{*}{0.875} \\
Alpha $\alpha$
\end{tabular}




\begin{tabular}{|c|c|c|c|c|c|c|}
\hline & PU03 & 0.786 & 16.359 & & & \\
\hline & PU04 & 0.784 & 16.865 & & & \\
\hline \multirow{3}{*}{$\begin{array}{l}\text { perceived Enjoyment } \\
\text { (EN) }\end{array}$} & EN1 & 0.941 & 30.839 & \multirow{3}{*}{0.772} & \multirow{3}{*}{0.909} & \multirow{3}{*}{0.844} \\
\hline & EN2 & 0.733 & 7.191 & & & \\
\hline & EN3 & 0.944 & 32.476 & & & \\
\hline \multirow{4}{*}{$\begin{array}{l}\text { Computer anxiety } \\
\text { (ANX) }\end{array}$} & ANX1 & 0.914 & 10.425 & \multirow{4}{*}{0.684} & \multirow{4}{*}{0.895} & \multirow{4}{*}{0.843} \\
\hline & ANX2 & 0.917 & 10.550 & & & \\
\hline & ANX3 & 0.705 & 6.822 & & & \\
\hline & ANX4 & 0.750 & 6.799 & & & \\
\hline \multirow{3}{*}{$\begin{array}{l}\text { Computer } \\
\text { playfulness } \\
\text { (CP) }\end{array}$} & CP1 & 0.968 & 111.508 & \multirow{3}{*}{0.882} & \multirow{3}{*}{0.957} & \multirow{3}{*}{0.932} \\
\hline & CP2 & 0.975 & 183.996 & & & \\
\hline & CP3 & 0.871 & 29.155 & & & \\
\hline
\end{tabular}

Table 4 Correlation matrix and discriminant validity.

\begin{tabular}{|c|c|c|c|c|c|c|c|c|}
\hline & AU & ATU & BI & ANX & EN & CP & PEOU & PU \\
\hline AU & 0.845 & & & & & & & \\
\hline ATU & 0.341 & 0.903 & & & & & & \\
\hline BI & 0.657 & 0.571 & 0.907 & & & & & \\
\hline ANX & -0.159 & -0.098 & -0.139 & 0.827 & & & & \\
\hline EN & 0.075 & 0.259 & 0.267 & 0.032 & 0.878 & & & \\
\hline CP & 0.317 & 0.515 & 0.502 & -0.163 & 0.257 & 0.939 & & \\
\hline PEOU & 0.397 & 0.533 & 0.482 & -0.226 & 0.255 & 0.539 & 0.757 & \\
\hline PU & 0.504 & 0.566 & 0.680 & -0.103 & 0.270 & 0.578 & 0.580 & 0.803 \\
\hline
\end{tabular}

\subsection{Structural Model and Hypotheses testing}

After Completing the measurement model and the overall results met the criteria of reliability and validity. Next, PLS-SEM assessment of the structural model which, was done by examining the capability of the model to explain the variance of dependent variables ( $\mathrm{R}^{2}$ values), significance of path coefficients and the t-statistics (Joseph F Hair, 2017). As the software is used in this study was smartpls, the bootstrap routine was running to examine the structural model relationships amongst the constructs. however, the bootstrap routine computes the empirical $\mathrm{p}$ and $\mathrm{t}$ values. Researchers usually set the critical values of a significance level to $5 \%$, for two-tailed tests is 1.96 , and for one-tailed tests is 1.65 . In fact, almost all researchers use $p$ values to judge significance levels. The results obtained are is presented in Table 6 . The twelve hypotheses presented in the previous parts of this paper were tested and the path significance of each hypothesis are also presented in this table. In addition, the variance(R2) of each path was examined (see Table 7).

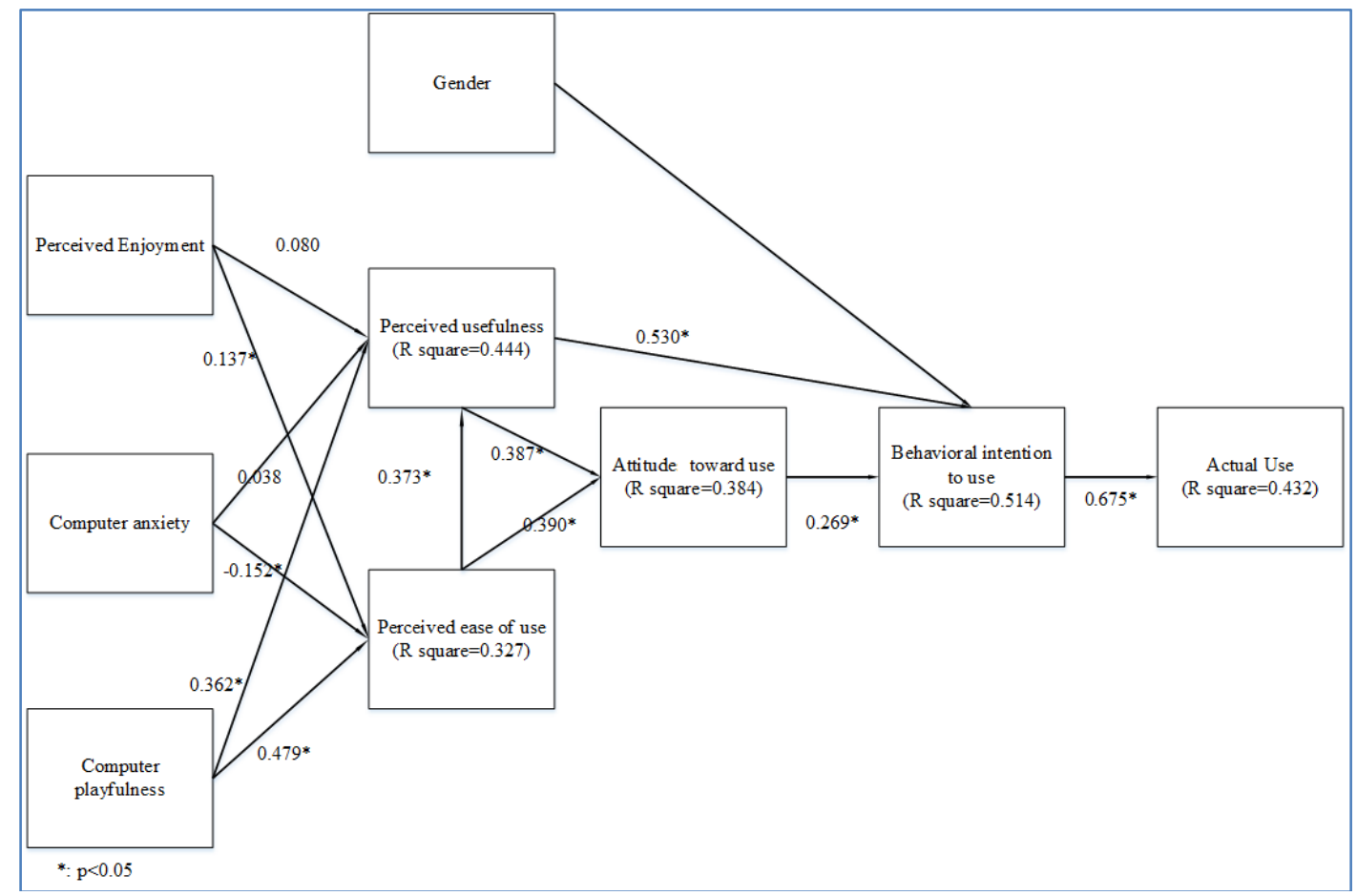

Figure2 Research model with results 
Citation: Mohamed Abugharsa, et al., A Modified Technology Acceptance Model to Analyze the Usage of Internet-Based Education Tool in Primary Schools in Libya. Australian Journal of Basic and Applied Sciences, 13(1): 28-43. DOI: 10.22587/ajbas.2019.13.1.5

Table 6 Path Coefficients

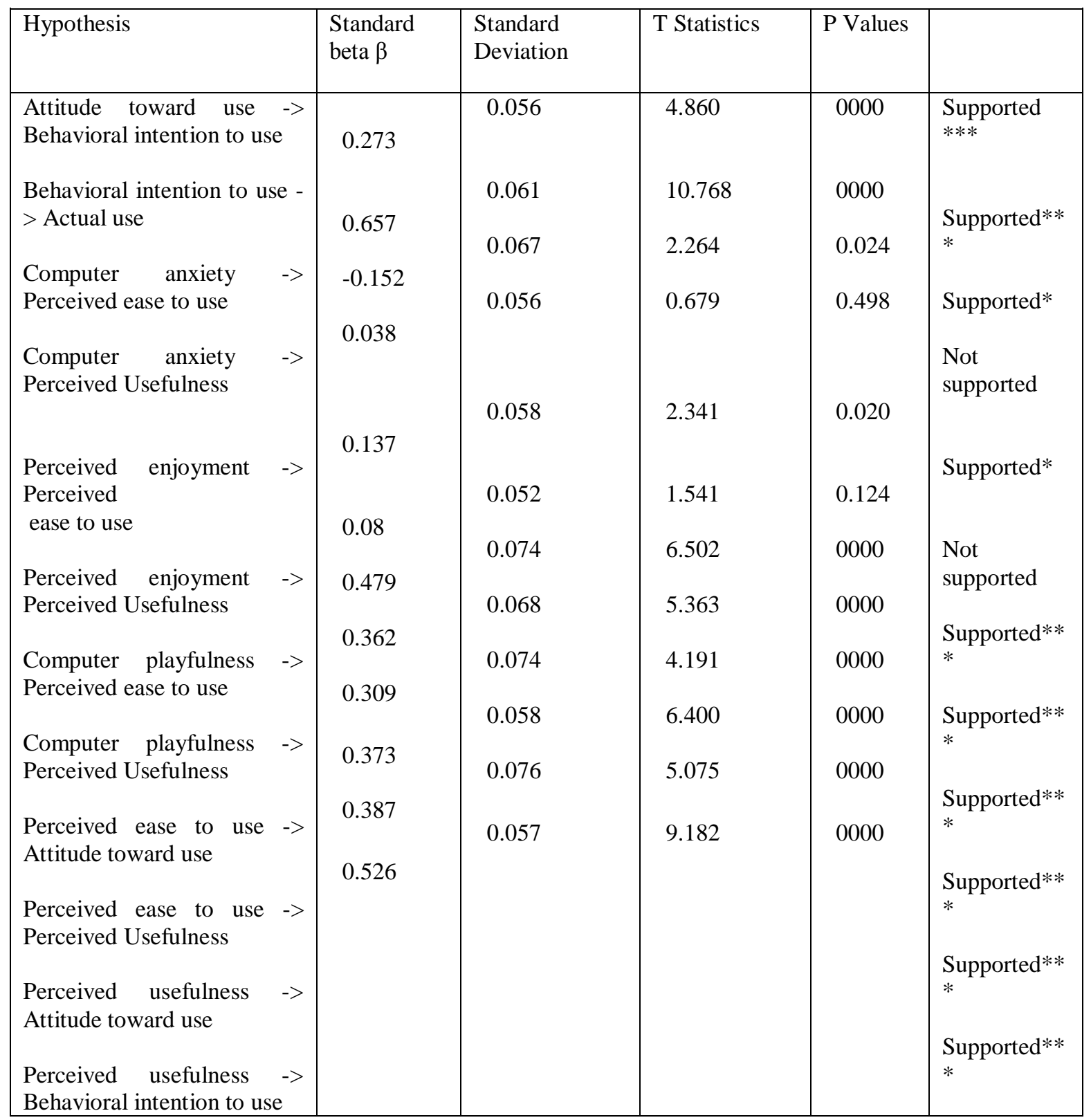

Note: $* * * p<0.001, * * p<0.01, * p<0.05$

Table 7 R square

\begin{tabular}{|l|l|l|}
\hline Constructs & R Square & Result \\
\hline Actual use & 0.432 & Moderate \\
\hline Attitude toward use & 0.384 & Moderate \\
\hline Behavioral intention to use & 0.514 & Moderate \\
\hline Perceived ease to use & 0.327 & Weak \\
\hline Perceived usefulness & 0.444 & Moderate \\
\hline
\end{tabular}

had a significant direct positive effect on Perceived usefulness of using a web-based learning system with standard $\beta=0.362$, and $\mathrm{p}<0.001$. In the main stream, hypothesis H10 is supported where Perceived enjoyment had a significant positive direct effect on Perceived ease of use of a web-based learning system since standard $\beta=0.137$, and $p<0.05$. On the other hand, the results have shown that, with hypothesis H9, Perceived enjoyment had no significant effect on Perceived usefulness of using a web-based learning system $(\beta=0.08, p=0.124)$ then this hypothesis must be rejected. The results of the study show that the hypothesis H12 is supported where Computer anxiety had a significant negative direct effect on Perceived ease of use of a web-based learning system when standard $\beta=-0.152$, and $\mathrm{p}<0.05$. Inconsistent with hypothesis H13, Computer anxiety had no significant effect on Perceived usefulness of using a web-based learning system with standard $\beta=0.038$, and $p=0.498$ ) where the hypothesis must be rejected. 
Citation: Mohamed Abugharsa, et al., A Modified Technology Acceptance Model to Analyze the Usage of Internet-Based Education Tool in Primary Schools in Libya. Australian Journal of Basic and Applied Sciences, 13(1): 28-43. DOI: 10.22587/ajbas.2019.13.1.5

In the terms of hypothesis 11 , an investigation has been done to determine if gender has a positive effect on Behavioral intention to use web-based learning system. To complete this examination, we applied multi-group analysis using PLS, and that by dividing our data into two groups Female and Male. The results show that there is no significant difference between males and females regarding the effect of behavioral intention to use of a web-based learning system. Male data more clearly supported the hypotheses the effects of Computer playfulness on Perceived usefulness of using a web-based learning system, and the effects of Perceived ease to use of a web-based learning system on Attitude to use web-based learning system more than females. On the other hand, female data supported the effects of Perceived usefulness on Attitude toward use of a web-based learning system, and the effect of behavioral intention to use on the actual use of web-based learning system; see Table 8.

Table 8 Gender differences

\begin{tabular}{|c|c|c|c|c|c|c|c|}
\hline Constructs & $\beta$ Female & $\beta$ Male & \multicolumn{2}{|c|}{ P female } & \multicolumn{2}{|c|}{$\mathrm{P}$ male } & \\
\hline Attitude toward use -> Behavioral intention to use & 0.256 & 0.283 & 0.001 & $* * *$ & 0.001 & $* * *$ & \\
\hline Behavioral intention to use $>$ Actual use & 0.746 & 0.578 & 0000 & $* * *$ & 0000 & **** & \\
\hline Computer anxiety $>$ Perceived ease to use & -0.107 & -0.224 & 0.244 & & 0.051 & & Not supported \\
\hline Computer anxiety $>$ Perceived usefulness & -0.002 & 0.12 & 0.979 & & 0.134 & & Not supported \\
\hline Perceived enjoyment $>$ Perceived ease to use & 0.118 & 0.194 & 0.059 & & 0.162 & & Not supported \\
\hline Perceived enjoyment $->$ Perceived usefulness & 0.084 & 0.063 & 0.243 & & 0.430 & & Not supported \\
\hline Computer playfulness -> Perceived ease to use & 0.5 & 0.454 & 0000 & $* * *$ & 0000 & $* * *$ & \\
\hline Computer playfulness -> Perceived usefulness & 0.274 & 0.419 & 0.005 & $*$ & 0000 & $* * *$ & \\
\hline Perceived ease to use $->$ Attitude toward use & 0.308 & 0.350 & 0.004 & $*$ & 0000 & $* * *$ & \\
\hline Perceived ease to use $->$ Perceived usefulness & 0.358 & 0.412 & 0000 & $* * *$ & 0000 & $* * *$ & \\
\hline Perceived usefulness $>$ Attitude toward use & 0.367 & 0.407 & 0000 & $* * *$ & 0.001 & $* *$ & \\
\hline Perceived usefulness > Behavioral intention to use & 0.508 & 0.540 & 0000 & $* * *$ & 0000 & $* * *$ & \\
\hline
\end{tabular}

The actual use construct was predicted by Behavioral intention to use, and this variable explained $43 \%\left(\mathrm{R}^{2}=0.432\right)$ of the variance in actual use, which is defined as moderate (Chin, 1998). Behavioral intention to use is predicted by attitude to use and perceived usefulness, and the two constructs explained $51.4 \%\left(\mathrm{R}^{2}=0.514\right)$ of the variance in behavioral intention to use, representing a high overall R-squared value. In addition, Attitude toward use of a web-based learning system was predicted by perceived ease of use of a web-based learning system, and perceived usefulness of using a web-based learning system, the two constructs explained $38.4 \%\left(\mathrm{R}^{2}=0.384\right)$ of the variance in attitude toward use of web-based learning system, which is defined as moderate. Perceived usefulness of using a web-based learning system was predicted by perceived ease of use, computer anxiety, perceived enjoyment, and computer playfulness. In all, the three constructs explained $44.4 \%\left(\mathrm{R}^{2}=0.444\right)$ of the variance in perceived usefulness of using web-based learning system, which is defined as moderate. Perceived ease of use was predicted by computer anxiety, perceived enjoyment, and computer playfulness, and the three constructs together explained $32.7 \%\left(\mathrm{R}^{2}=0.327\right)$ of the variance in perceived ease of use of a web-based learning system, which is defined as weak (Chin, 1998).

\subsection{Direct and Indirect effects}

Mediation is said to be present when the direct path coefficient between the independent variable and dependent variable declines, or when the indirect path through the mediator is created in the model. Prior testing of the significance of mediating effects relied on the Sobel test (1982). The Sobel test assumes a normal distribution that is not, however, consistent with the nonparametric PLS-SEM method. Instead of using the Sobel test, researchers should bootstrap the sampling distribution of the indirect effect (Preacher \& Hayes, 2004, 2008a). This is therefore perfectly suited for the PLS-SEM method and can be implemented using the SmartPLS 3.2.7 software. In addition, bootstrapping the indirect effect yields higher levels of statistical power when compared with those of the Sobel test. The analysis of a multiple mediation model, the researcher should test whether the total indirect effect is significant, and test bootstrapping confidence interval (low and upper level), as in Table 9. To test if there is mediation effect, we need first to test if the effect is significant or not ( $p$ value). If significant, we test the confidence interval's lower and upper levels for no zero value between therefore, we check the standard $\beta$ since standard $\beta$ beta is between -1 to 1 the strong effect is when standard $\beta$ close to 1 on both sides.

Table 9 Analysis of total Indirect effects

\begin{tabular}{|c|c|c|c|c|c|}
\hline & Indirect effect & $\begin{array}{c}\text { 95\%Confident } \\
\text { interval of } \\
\text { indirect effect }\end{array}$ & t value & $\begin{array}{c}\text { Significance } \\
\mathrm{p}<0.005\end{array}$ & P value \\
\hline ATU-AU & 0.180 & $0.116,0.259$ & 4.795 & Yes & 000 \\
\hline
\end{tabular}


Citation: Mohamed Abugharsa, et al., A Modified Technology Acceptance Model to Analyze the Usage of Internet-Based Education Tool in Primary Schools in Libya. Australian Journal of Basic and Applied Sciences, 13(1): 28-43. DOI: 10.22587/ajbas.2019.13.1.5

\begin{tabular}{|c|c|c|c|c|c|}
\hline ANX-AU & -0.016 & $-0.067,0.033$ & 0.6 & No & 0.549 \\
\hline ANX-ATU & -0.054 & $-0.118,0.012$ & 1.457 & No & 0.146 \\
\hline ANX-BI & -0.025 & $-0.094,0.053$ & 0.617 & No & 0.537 \\
\hline ANX-PU & -0.057 & $-0.109,-0.015$ & 2.146 & Yes & 0.032 \\
\hline EN-AU & 0.062 & $0.002,0.118$ & 2.137 & Yes & 0.033 \\
\hline EN-ATU & 0.093 & $0.011,0.189$ & 2.034 & Yes & 0.043 \\
\hline EN-BI & 0.095 & $-0.002,0.189$ & 1.934 & No & 0.054 \\
\hline EN-PU & 0.051 & $0.007,0.101$ & 2.02 & Yes & 0.044 \\
\hline CP-AU & 0.251 & $0.183,0.310$ & 6.766 & Yes & 000 \\
\hline CP-ATU & 0.357 & $0.201,0.497$ & 4.54 & Yes & 000 \\
\hline CP-BI & 0.382 & $0.246,0.520$ & 5.14 & Yes & 000 \\
\hline CP-PU & 0.179 & $0.103,0.265$ & 4.114 & Yes & 000 \\
\hline PEOU-AU & 0.210 & $0.147,0.276$ & 6.103 & Yes & 000 \\
\hline PEOU-ATU & 0.144 & $0.083,0.227$ & 4.046 & Yes & 000 \\
\hline PEOU-BI & 0.320 & $0.200,0.419$ & 5.358 & Yes & 000 \\
\hline PU-AU & 0.415 & $0.349,0.483$ & 11.906 & Yes & 000 \\
\hline PU-BI & 0.106 & $0.057,0.205$ & 3.157 & Yes & 0.002 \\
\hline
\end{tabular}

Table 10 Analysis of total effects

\begin{tabular}{|c|c|c|c|c|}
\hline Dependent variable & Independent Variables & Direct Effects & Indirect Effects & Total Effects \\
\hline \multirow{4}{*}{ Actual Use } & Behavioral intention to use & 0.657 & --- & 0.657 \\
\cline { 2 - 5 } & Attitude toward use & & 0.18 & 0.18 \\
\cline { 2 - 5 } & Perceived ease to use & & 0.21 & 0.21 \\
\cline { 2 - 5 } & Perceived Usefulness & & 0.415 & 0.415 \\
\cline { 2 - 5 } & Computer anxiety & & -0.016 & -0.016 \\
\cline { 2 - 5 } & Perceived enjoyment & & 0.062 & 0.062 \\
\cline { 2 - 5 } & Computer playfulness & & 0.251 & 0.251 \\
\hline
\end{tabular}

\section{IMPLICATIONS AND CONCLUSIONS}

\subsection{Theoretical and practical implications}

The findings of the 13 hypotheses in this study contribute variance to actual use and corroborate the findings of the technology acceptance model created by Davis (1989). Nine hypotheses of the eleven have been accepted, and two hypotheses have been rejected.

In this empirical study, we analyzed the acceptance of a web-based learning system from the perspective of teachers, educational experts, and workers in Libyan primary schools. In the beginning we analyzed the relationships between the three external variables (perceived enjoyment, computer playfulness, and computer anxiety) and perceived usefulness among with perceived ease of use. Later, we analyzed the relationships between the perceived ease of use and both perceived usefulness and attitude toward use of a web-based learning system. In addition, we analyzed the relationship between perceived usefulness, attitude toward use, and gender with behavioral intention to use of a web-based learning system. Finally, we investigated the relation between behavioral intention to use a web-based learning system with actual use of a web-based learning system.

The study found that Computer playfulness (CP) significantly and positively influences the school teacher's belief in the usefulness of web-based learning system and has a significant indirect effect on attitude toward use, behavioral intention to use a web-based learning system, and actual use of a web-based learning system. On the other hand, computer anxiety (CA) has a negative effect on the school teachers' belief in the usefulness of a web-based learning system, which is supported by the findings of Purnomo and Lee (2013) and Park et al. (2012). However, this is not in agreement with the results of Saade and Kira (2006) or Liu (2010), who had found that CA does not influence students' e-learning, the only indirect effect that computer anxiety has on perceived usefulness. Many researchers have found that anxiety has the most significant effect on perceived ease of use, and that this is greater than its effect on perceived usefulness. Venkatesh, 2000 confirmed our findings in this study. Perceived enjoymentt (EN) significantly and positively influences the school teacher's belief in the ease of use of a web-based learning system but does not have an effect on perceived usefulness. in addition of that, EN has an indirect effect on perceived usefulness, attitude toward use, and actual use. According to TAM, perceived enjoyment had the largest effect on perceived usefulness, followed by perceived ease of use, attitude toward use, and intention to use. This finding is contrary to existing work which found that perceived enjoyment affects perceived usefulness indirectly via perceived ease of use (Venkatesh, 2000). Consistent with the literature, this study found a significant relationship between perceived enjoyment and perceived ease of use $(\beta=0.137, \mathrm{p}<0.025)$. Furthermore, Perceived ease of use (PEOU) has a significant and positive influence on the school stakeholders' (students, teachers, eperts and school managers) attitude toward use of a web-based learning system and on perceived usefulness. These findings are supported by the finding of previous studies (Davis, 1989; Davis et. al., 1989; Jackson, Chow, \& Leitch, 1997; Mathieson, 1991; Moore \& Benbasat, 1991; Thong et al., 2004). In addition, many researchers confirmed that as more web-based learning systems are easier to use will be more used by stakeholders will support the usage of web-based learning system (Andersson, 2006; Hayes, 
Citation: Mohamed Abugharsa, et al., A Modified Technology Acceptance Model to Analyze the Usage of Internet-Based Education Tool in Primary Schools in Libya. Australian Journal of Basic and Applied Sciences, 13(1): 28-43. DOI: 10.22587/ajbas.2019.13.1.5

2007; Russell et al., 2003). Likewise, perceived ease of use has a significant indirect effect on attitude toward use of a web-based learning system, behavioral intention to use a web-based learning system, and actual use of a web-based learning system. The findings reveal that participants accept a web-based learning system not because of its known benefits but because it is perceived to be practical and efficient. This indicates that participants have accepted web-based learning systems and are confident of that the use of such a system enhances their work and the use of the system does not require much effort.

Many researchers have shown that perceived ease of use usually directly affects behavioral intention to use, particularly in early stages when the user starts using the system. As the user gains experience with using the system and becomes more familiar with it, the direct effects of perceived ease of use become weaker and turn into be indirect effects instead of direct effect via perceived usefulness (Davis et al., 1989; Van Raaij \& Schepers, 2008). the user carries on using the system only through his or her believes the system is usefulness (Ma et al., 2005; Szajna, 1996). We took this into account and reviewed the answers to the demographics questions of our survey, in which almost all of the respondents have acceptable experience in using computers and the Internet. This leads us to the fact that teachers and people working in the education field have moved from the stage of ease of use to the stage of usefulness.

In addition, the results of our study showed that the perceived usefulness of using a web-based learning system significantly and positively influences school respondents' attitude toward use of a web-based learning system. This holds true for behavioral intention to use a web-based learning system as well, and these findings are confirmed by the previous study that found perceived usefulness of using a web-based learning system is the main predictor of an individual's intention to use a particular system (Davis, 1989; Venkatesh and Davis, 2000; Venkatesh et al., 2003). Ingeneral, the results also tell us that perceived usefulness of using web-based learning system has more impact on behavioral intention to use of a web-based learning system than attitude toward use of a web-based learning system, and Perceived usefulness of using a web-based learning system has a stronger direct effect on attitude toward use of a web-based learning system than perceived ease of use, therefore. In terms of indirect effects, perceived usefulness of using a web-based learning system has significant and positive indirect effects on behavioral intention to use a web-based learning system and actual use of a web-based learning system. However, when compared with studies that have been done in the same field, the results of this study shows that behavioral intention to use a web-based learning system increases when the perceived usefulness of using the web-based learning is improved (Andersson, 2006; Ma et al., 2005; Rogers \& Finlayson, 2004; Zhao, 2007). With that information in mind, teachers' requirements and considerations should be involved when developing and designing web-based learning systems in order to create a system that is beneficial and valuable for the teachers who use it.

The study found that attitude toward use of a web-based learning system has a significant positive direct effect on behavioral intention to use a web-based learning system, and an indirect effect on actual use of a web-based learning system, and previous studies have confirmed that (Venkatesh, Morris, Davis, \& Davis, 2003).

The results of this study show that behavioral intention to use has significantly influenced the actual use of a web-based learning system as tools in Libyan primary schools. This is supported by Davis (1989), who found that behavioral intention to use determines the actual usage. In addition, another study found that behavioral intention to use is the strongest determinant of actual use (Taylor \& Todd 1995). In addition of that, our study has revealed that teachers' behavioral intention to use a web-based learning system has significantly and positively influenced actual use of web-based learning systems in Libyan Primary schools. This study revealed that the intention to use a web-based learning system by the teachers in Libyan primary schools will increase when the teachers and the people working in the educational field in these schools view the system as exciting and enjoyable to use, (and intention to use increases), the teachers will start using the system actively, which will lead to better use of the system (Cuban, 2003; Russell et al., 2003; Zhao, 2007).

Regarding the effects of gender differences on Behavioral intention to use a web-based learning system, the results has revealed that females have more effect in term of the influence of behavioral intention to use web-based learning system on actual use then males, while males have shown more influence in term of the effecting of perceived playfulness on perceived usefulness. However, the rest of the results show no significant effect for gender differences on the relationship between the other variables and constructs, and this is supported by the findings of Tasi and Lin (2004), Chen and Lin (2002), Al-Harbi (2010).

In conclusion, this study has developed an extended model to investigate and predict the factors that affect the adoption of webbased learning systems as teaching tools in primary level Libyan schools by integrating the concepts of user behavioral intention to use, beliefs and some external variables. The structural equation modeling technique was used to examine the proposed model of this study. However, the study has provided valuable and acceptable results that could be used to improve the usage of webbased learning systems as educational tools in Libyan primary schools and these results are significantly supported by previous studies. In addition, nine of our11 proposed hypotheses were found to be significantly supported, which provided us with a unique understanding of respondents' acceptance of web-based learning systems in Libyan primary schools.

\subsection{Limitation and Future work}

In terms of limitations, as our study intended to determine the factors that affect the usage of web-based learning systems in Libyan primary schools, as well as the study focus on the adoption of this tools in primary schools. However, we obtained the responses from the teachers and people who work in this field of education (primary schools) which provided results that might be not generalizable to the acceptance of web-based learning systems in different contexts, like high schools and other similar institutes. In addition of, as the study proposed a theoretical model that integrated some exogenous constructs as well as some external variables which explained a significant amount of the variance of the actual use of a web-based learning system in Libyan primary schools with the values of $\mathrm{R}^{2}=0.432$. Therefore, to achieve better understanding of the acceptance of web-based learning systems in various institutions in Libya we support further research to gain a better understanding by investigating the impacts and the influence of other exogenous constructs and other external variables. 
Citation: Mohamed Abugharsa, et al., A Modified Technology Acceptance Model to Analyze the Usage of Internet-Based Education Tool in Primary Schools in Libya. Australian Journal of Basic and Applied Sciences, 13(1): 28-43. DOI: 10.22587/ajbas.2019.13.1.5

\section{ACKNOWLEDGEMENT}

This research was supported by The Libyan Ministry of High Education, full scholarship was given to Mohamed Abugharsa. This paper is a part of thesis of Mohamed Abugharsa that is supervised by Dr. Gulsah Hancerliogullari Koksalmis and Dr. Ümit Tokeşer.

\section{CONFLICT OF INTEREST}

Authors declare no conflict of interest

\section{REFERENCES}

Abdel-Wahab, A.G. (2008). Modeling Students' Intention to Adopt E-Leaning: A

Case from Egypt. The Electronic Journal of Information System in Developing Countries (EJISDC), Vol. 34 (1), pp. 1-13.

Agarwal, R., \& Karahanna, E. (2000). Time flies when you're having fun: Cognitive absorption and beliefs about information technology usage. MIS Quarterly, 24(4), 665-694.

Ajzen, I., \& Fishbein, M. (1980). Understanding attitudes and predicting social behaviour. Englewood Cliffs, New Jersey: Printice-Hall.

Al-Harbi, K.R.A-S. (2010). Investigating Factors Influencing the Adoption of E-learning: Saudi Students Perspective. PhD thesis, (Thesis Submitted for the Degree of Doctor of Philosophy at the University of Leicester), University of Leicester, School of Education.

Al-Zaidiyeen, N., Mei, L., \& Fook, F. (2008). In-Service Teachers' Attitudes Towards The Use of Informationand Communication Technology in Teaching Practice: The cas of Jordan. Proceeding of Paper presented at the the 2nd International Malaysian Educational Technology Convention, , Kuantan,Pahang Darul Makmur, Malaysia.

Ali Mohamed Elkaseh1, Kok Wai Wong, and Chun Che Fung. The Acceptance of E-learning as a Tool for Teaching and Learning in Libyan Higher Education. IPASJ International Journal of Information Technology (IIJIT) 2015.

Amoako-Gyampah, K. (2007). Perceived usefulness, user involvement and behavioral intention: an empirical study of ERP implementation. Computers in Human Behavior 23, 1232-1248.

Andersson, S. B. (2006). Newly qualified teachers' learning related to their use of information and communication technology: A Swedish perspective. British Journal of Educational Technology, 37(5), 665-682.

Arenas-Gaitan, J., Rondan-Cataluña, F. J., and Ramirez-Correa, P. E. (2010). Gender influence in perception and adoption of elearning platforms. Proceedings of the 9th WSEAS International Conference on Advance in Networks, Communications, Computers, 2010, November, Faro, Portugal, pp. 30-34.

Astleitner, H., and Steinberg, R. (2005). Are there gender differences in web-based learning? An integrated model and related effect sizes. AACE Journal, Vol.13 (1), pp.47-63.

Aziz, S., \& Hassan, H. (2012). A study of computer anxiety of higher secondary students in Punjab. International journal social science and education, 2, 264-273.

Bandura, A. (1989). Human agency in social cognitive theory. American Psychologist, 44, 1175-1184.

Bruner, G. C., \& Kumar, A. (2005). Explaining consumer acceptance of handheld Internet devices. Journal of Business Research, 58(5), 553-558.

Chang, H., \& Wang, I. (2008). An investigation of user communication behaviour in computer mediated environments. Computers in Human Behaviour, 24 (5), 2336-2356. DOI: 10.1016/j.chb.2008.01.001.

Chang, S. C. \& Tung, F. C. (2008). An empirical investigation of students' behavioural intentions to use the online learning course websites. British Journal of Educational Technology 39, 71-83.

Chatzoglou, P. D., Sarigiannidis, I., Vramaki, E, \& Diamntisis, A. (2009). Investigating Greek employees' intention to use webbased training. Computer \& Education, 53(3), 877-889.

Chen, H-R., and Tseng, H-F. (2012). Factors that influence acceptance of web-based e-learning systems for the in-service education of junior high school teachers in Taiwan. Evaluation and Program Planning, Vol. 35, pp.398-406.

Chesney, T. (2006). An acceptance model for useful and fun information systems.

Chen, R. S., and Tsai, C. C. (2007). Gender differences in Taiwan university students' attitudes toward web-based learning. Cyberpsychology and Behavior, Vol.10 (5), pp.645-654.

Chen, N. S., and Lin, K. M. (2002). Factors affecting e-learning for achievement. Available at: Ittf.ieee.org/icalt2002/proceedings/t502_icalt148_End.pdf.

C.L.Hsu and H.P.Lu, "Why do people play online games? An extended TAM with social influences and flow experience", Information \& Management, vol.41, no.7, pp. 853-868, 2004

Csikszentmihalyi, M., 1990. Flow: The Psychology of Optimal Experience. Harper and Row, New York.

Chin, K. L., and Kon, P. N. (2004). Critical Success Factors for E-Learning. Available at: http://www.iadis.net/dl/final_uploads/2004021030.pdf.

Chin, W. W. (1998b). The partial least squares approach to structural equation modeling. In G. A. Marcoulides (Ed.), Modern methods for business research (pp. 295-336). London: Lawrence Erlbaum Associates.

Cuban, L. (2003). Oversold and underused: Computers in the classroom. Cambridge, MA: Harvard University Press.

Cuban, L. (2003). Oversold and underused: Computers in the classroom. Cambridge, MA: Harvard University Press. 
Citation: Mohamed Abugharsa, et al., A Modified Technology Acceptance Model to Analyze the Usage of Internet-Based Education Tool in Primary Schools in Libya. Australian Journal of Basic and Applied Sciences, 13(1): 28-43. DOI: 10.22587/ajbas.2019.13.1.5

Davis Fred D. Perceived usefulness, perceived ease of use, and user acceptance of information technology. MIS Quarterly. 1989;319-340.

Davis, F. D. (1989). Perceived usefulness, perceived ease of use, and user acceptance of information technology. MIS Quarterly, 13, 319-340.

Davis, F. D., Bagozzi, R. P., \& Warshaw, P. R. (1989). User acceptance of computer technology: a comparison of two theoretical models. Management Science, 35(8), 982-1003.

Davis, F.D., Bagozzi, R.P., Warshaw, P.R., 1992. Extrinsic and intrinsic motivation to use computers in the workplace. Journal of Applied Social Psychology 22, 1111-1132.

Doll, W. J., Hendrickson, A., and Deng, X. (1998), “Using Davis's Perceived Usefulness and Ease of-use Instruments for Decision Making: A Confirmatory and Multigroup Invariance Analysis”, Decision Sciences Journal, Vol. 29, No. 4, pp. 839869.

Efron, B., \& Tibshirani, R. J. (1993). An introduction to bootstrap In Monographs on statistics and applied probability, Vol. 57. New York, NY: Chapman and Hall.

Falk, R.F., Miller, N.B., 1992. A Primer for Soft Modeling. The University of Akron,

Akron, OH.F. D. Davis, R. P. Bagozzi, and P. R. Warshaw, "Extrinsic and intrinsic motivation to use computers in the workplace1," Journal of applied social psychology, vol. 22, pp. 1111-1132, 1992.

F.D.Davis," Perceived Usefulness, Perceived Ease of Use, and User Acceptance of Information Technology", MIS Quarterly, vol.13, no.3, pp. 319 - 340, 1989. Fishbein, M., \& Ajzen, I. (1975). Belief, Attitude, Intention, and Behavior: An Introduction to Theory and Research. Reading. MA: Addison-Wesley.

Fornell, C., Bookstein, L., 1982. Two structural equation models: LISREL and PLS applied to consumer exit-voice theory. Journal of MarketingResearch 19, 440-452.

Franklin, C. (2007). Factors that influence elementary teachers' use of computers. Journal of Technology and Teacher Education, 15(2), 267-293.

Friedrich, H.F., and Hron, A. (2010). Factors Influencing Pupils' Acceptance of an E-Learning System for Secondary Schools. Journal Educational Computing Research, Vol. 42, pp. 63-78. Available at: http://www.eric.ed.gov/ERICWebPortal/recordDetail?accno=EJ872026.

Gardner, D. G., Discenza, R., \& Dukes, R. (1993). The measurement of computer attitudes: An empirical comparison of the available scales. Journal of Educational Computing Research. 9, 487-507.

Gefen, D., Karahanna, E. \& Straub, D. W. (2003a). Inexperience and experience with online stores: The importance of TAM and trust. IEEE Transactions on Engineering Management, 50(3), 1-15.

Gefen, D., Karahanna, E. \& Straub, D. W. (2003b). Trust and TAM in online shopping: An integratedmodel. MIS Quarterly, 27(1), 51-90.

Gefen, D., \& Straub, D. W. (1997). Gender difference in the perception and use of e- mail: An extension to the technology acceptance model. MIS Quarterly, 21(4), 389-400.

Gilroy, F. D., \& Desai, H. B. (1986). Computer anxiety: sex, race and age. International Journal of Man-Machine Studies, 25, 711-719.

Gonzalez-Gomez, F., Guardiola, J., Rodríguez, O. M., and Alonso, M. A. M.(2012).

Gender differences in e-learning satisfaction. Computers and Education, Vol.58 (1), pp.283-290.

Hammoud, L., Love, S., Baldwin, L., and Chen, S.Y. (2008). Evaluating WebCT Use in Relation to Students' Attitudes and Performance. International Journal of Information and Communication Technology Education, Vol. 4(2), IGI Publishing.

Heinssen, R. K. Jr., C. R. Glass, L. A. Knight. 1987. Assessing computer anxiety:

Development and validation of the computer anxiety rating scale. Computers in Human Behavior 3(1) 49-59. Igbaria M and Chakrabarti A (1990) Computer anxiety and attitudes towards microcomputer use. Behav.Inform. Technol. 9, $229-241$.

Jackson, C. M., Chow, S., \& Leitch, R. A. (1997). Toward an understanding of the behavioural intentions to use an information system. Decision Sciences, 28, 357-389.

J.C.Lin and H. Lu, "Towards an understanding of the behavioural intention to use a web site" International Journal of Information Management, vol.20, no.3, pp.197-208, 2000.

J.-H. Huang, Y.-R. Lin, and S.-T. Chuang, "Elucidating user behavior of mobile learning: A perspective of the extended technology acceptance model," Electronic Library, The, vol. 25, pp. 585-598, 2007.

J. Webster, Playfulness and computers at work, Unpublished Doctoral Dissertation, New York University, 1989.

Jung, I. (2012). Asian learners' perception of quality in distance education and gender differences. International Review of Research in Open and Distance Learning, Vol. 13(2), pp.1-25.

Joseph F Hair, G. Tomas M. Hult, Christian M. A Primer on Partial Least Squares Structural Equation Modeling (PLS-SEM), 2017.

Keller, C., Hrastinski, S., and Carlsson, S. (2007). Students' acceptance of e-learning

environments: A comparative study in Sweden and Lithuania. In Österle, S. J, (Ed.), Proceedings of the Fifteenth European Conference on Information Systems (pp. 395-406). St. Gallen: University of St. Gallen. DOI: http://urn.kb.se/resolve? urn=urn: nbn:se: hj:diva-3099.

Ke, C-H., Sun, H-M., Yang, Y-C.(2012). effects of user and system characteristics on perceived usefulness and perceived ease of use for the web-based classroom response system. tojet: The Turkish Online Journal of Educational Technology - July 2012, Vol. 11 (3), pp.128-134.

Khan, B. (2005). Managing E-Learning Strategies: Design, delivery, implementation and evaluation. Hershey,PA: Information Science Publishing. 
Citation: Mohamed Abugharsa, et al., A Modified Technology Acceptance Model to Analyze the Usage of Internet-Based Education Tool in Primary Schools in Libya. Australian Journal of Basic and Applied Sciences, 13(1): 28-43. DOI: 10.22587/ajbas.2019.13.1.5

Lai, C-M., Huang, H-M., Liaw, S-S, \& Huang, W-W. (2009). A study of user's acceptance on three dimensional virtual reality applied in medical education. Bulletin of Educational Psychology, 40(3), 341-362.

Landry, B. J. L., Griffeth, R. \& Hartman, S. (2006). Measuring student perceptions of blackboard using the technology acceptance model. Decision Sciences Journal of Innovative Education 4, 87-99.

Lee, M. (2010). Explaining and predicting user's continuance intention toward e learning: An extension of the expectationsconfirmation model. Computers \& Education, 54(2), 506-516.

Lee, Y., Kozar, K., \& Larsen, K. (2003). The technology acceptance model: Past, present, and future.Communications of the Association for Information Systems, 12, 752-780.

Lee, S. M., \& Chen, L. (2010). The impact of flow on online consumer behavior. Journal of Computer Information System, 50(4), $1-10$.

Lee, Y-C. (2006). An empirical investigation into factors influencing the adoption of an e-learning system. Online Information Review, Vol. 30 (5), 2006,pp. 517-541. Emerald Group Publishing Limited.

Liaw, S. S. (2008). Investigating students' perceived satisfaction, behavioral intention, and effectiveness of e-learning: A case study of the Blackboard system. Computers and Education, 51(2), 864-873.

Liu, S., Liao, H., \& Pratt, J.A. (2009). Impact of media richness and flow on e-learning technology acceptance. Computer \& Education, 52(3), 599-607.

Liu, I. F., Chen, M. C., Sun, Y. S., Wible, D. \& Kuo, C. H. (2010). Extending the TAM model to explore the factors that affect Intention to Use an Online Learning Community. Computers \& Education 54, 600-610.

Liu, S. H., Liao, H. L. \& Peng, C. J. (2005). Applying the Technology Acceptance Model And Flow Theory to Online E-learning Users' Acectpance Behavior. E-learning 4, H8.

Ma, W. W.-K., Andersson, R., \& Streith, K.-O. (2005). Examining user acceptance of computer technology: An empirical study of student teachers. Journal of Computer Assisted Learning, 21(6), 387-395.

Mahdizadeh, H., Biemans, H., and Mulder, M. (2008). Determining factors of the use of e-learning environments by university teachers. Computer and Education, Vol. 51, pp. 142- 154.

M. K. Lee, C. M. Cheung, and Z. Chen, "Acceptance of Internet-based learning medium: the role of extrinsic and intrinsic motivation," Information \& management, vol. 42, pp. 1095-1104, 2005.

Manal altawallbeh, Wun Thiam, Sultan alshourah, Soon Fook Fong. The Role of Age and Gender in the Relationship between (Attitude, Subjective Norm and Perceived Behavioural Control)and Adoption of E-Learning at Jordanian Universities. Journal of Education and Practice ISSN 2222-1735 (Paper) ISSN 2222-288X (Online)Vol.6, No.15, 2015.

Masoumi, D. (2006). Critical factors for effective E-learning. [Online] accessed at: http://www.e-quality-eu.org/pdf/seminar/eQuality_WS3_DMasoumi.pdf.

Mathieson, K. (1991). Predicting user intentions: Comparing the technology acceptance model with the theory of planned behaviour. Information Systems Research, 2(3), 173-191.

Moon, J. W., \& Kim, Y. G. (2001). Extending the TAM for a World-Wide-Web context. In-formation \& Management, 38(4), $217-230$

Moore, G. C., \& Benbasat, I. (1991). Development of an instrument to measure the perceptions of adopting an information technology innovation. Information Systems Research 2, 192-222.

Morris, M. G., V. Venkatesh. 2000. Age differences in technology adoption decisions: Implications for a changing workforce. Personnel Psych. 53 375-403.

Morrow PC, Prell ER and McElroy JC (1986) Attitudinal and behavioral correlates of computer anxiety. Psychol. Rep. 59, 11991204.

M. Ally and M. Gardiner, "Application and device characteristics as drivers for smart mobile device adoption and productivity," International Journal of Organizational Behaviour, vol. 17, pp. 35-47, 2012.

M. Y. Yi and Y. Hwang, "Predicting the use of web-based information systems: self-efficacy, enjoyment, learning goal orientation, and the technology acceptance model," International journal of human-computer studies, vol. 59, pp. 431-449, 2003.

Ngai, E. W. T., Poon, J. K. L., \& Chan, Y. H. C. (2007). Empirical examination of the adoption of WebCT using TAM. Computers \& Education, 48, 250-267.

Novak, T. P., Hoffman, D. L., \& Yung, Y. F. (2000). Measuring the customer experience in online environments: A structural modeling approach. Marketing Science, 19, 22-42.

Okazaki, S., and Santos, L. M. R. D. (2012). Understanding E-Learning Adoption in Brazil: Major Determinants and Gender Effects. The International Review of Research in Open and Distance Learning (IRRODL), Vol. 13(4), Oct. (2012), pp.91-106.

Ong, C. S., and Lai, J. Y. (2006). Gender differences in perceptions and relationships among dominants of e-learning acceptance. Computers in Human Behavior, Vol.22 (5), pp.816-829.

Owens, J.D., and Price, L. (2010). Is E-Learning replacing the traditional Lecture? Education and Training Journal, Vol. 52(2), pp. 128-139.

Park Sung Youl. An analysis of the technology acceptance model in understanding university students. Behavioral Intention to Use e-Learning. Educational Technology \& Society. 2009;12(3): 150-162.

Pedersen, P., \& Nysveen, H. (2003). Usefulness and self-expressiveness: Extending TAM to explain the adoption of a mobile parking services, In the Proceeding of 16th Beld eCommerce Conference, Bled, Slovenia, June 9-11.

P.K. Chau, and P.J. Hu, " Information technology acceptance by individual professionals", Decision Sciences, vol.32, no.4, pp.699-710, 2001. 
Citation: Mohamed Abugharsa, et al., A Modified Technology Acceptance Model to Analyze the Usage of Internet-Based Education Tool in Primary Schools in Libya. Australian Journal of Basic and Applied Sciences, 13(1): 28-43. DOI: 10.22587/ajbas.2019.13.1.5

Pituch, K.A., and Lee, Y-K. (2006). The influence of system characteristics on e-learning use. Computer and Education, Vol. 47, pp.222-224. Available online at http://www.scincedirect.com.

Preacher, K. J., \& Hayes, A. F. (2008a). Asymptotic and resampling strategies for assessing and comparing indirect effects in simple and multiple mediator models. Behavior Research Methods, 40, 879-891.

Preacher, K. J., \& Hayes, A. F. (2008b). Contemporary approaches to assessing mediation in communication research. In A. F. Hayes, M. D. Slater, \& L. B. Snyder (Eds.), The SAGE sourcebook of advanced data analysis methods for communication

research (pp. 13-54). Thousand Oaks, CA: Sage.

Raaij, E. M., \& Schepers, J. J L. (2008). The acceptance and use of a virtual learning environment in China. Computer \& Education, 50(3), 838-852.

Raman, A. (2011). The usage of technology among education students in University Utara Malaysia: An application of extended Technology Acceptance Model. International Journal of Education and Development using Information and Communication

Technology (IJEDICT), 2011, Vol. 7 (3), pp. 4-17.

Roca, J. C., \& Gagné, M. (2008). Understanding e-learning continuance intention in the workplace. A self-determination theory perspective. Computers in Human Behavior, 24(4), 1585-1604.

Rodriguez, T. \& Lozano, P. (2011). The acceptance of Moodle technology by business administration students. Computers \& Education.

Rogers, L., \& Finlayson, H. (2004). Developing successful pedagogy with information and communications technology: How are science teachers meeting the challenge? Technology, Pedagogy and Education, 13(3), 287-305.

Russell, G., \& Bradley, G. (1997). Teachers' computer anxiety: implications for professional development. Education and Information Technologies, 2, 17-30.

Russell, M., Bebell, D., O’Dwyer, L., \& O’Connor, K. (2003). Examining teacher technology use: Implications for preservice and inservice teacher preparation. Journal of Teacher Education, 54(5), 297-310.

Saadé, R. G. \& Galloway, I. (2005). Understanding intention to use multimedia information systems for learning. Informing Science: International Journal of an Emerging Transdiscipline 2, 287-296.

Selim, H. M. (2007a). Critical Success Factors for e-Learning Acceptance: Confirmatory Factors Models. Computer and Education, Vol. 49, pp.396- 413.

S.E. Yager, L.A. Kappleman, G.A. Maples, V.R. Prybutok, Microcomputer playfulness: stable or dynamic trait, Data Base 28 (2), 1997, pp. 43-51.

S.H. Wildstrom, They're mad as hell out there, Business Week 3600, 1998, pp. 32-33. T. McCarroll, What new age? Time 138 (6), 1991, pp. 44-46.

Shroff, R. H., Deneen, C. D. \& Ng, E. M. W. (2011). Analysis of the technology acceptance model in examining students' behavioural intention to use an e-portfolio system. Australasian Journal of Educational Technology, 27(4), 600-618. Retrieved from http://www.ascilite.org.au/ajet/ajet27/shroff.html.

Shen, J., \& Eder, L. B. (2009). Exploring intentions to use virtual worlds for business. Jour-nal of Electronic Commerce Research, 10(2), 94-103.

S. Y. Park, "An Analysis of the Technology Acceptance Model in Understanding

University Students' Behavioral Intention to Use e-Learning," Educational Technology \& Society, vol. 12, pp. 150-162, 2009.

Sobel, M. E. (1982). Asymptotic confidence intervals for indirect effects in structural equation models. Sociological Methodology, 13, 290-312.

Snchez-Franco, M. J., Martnez-Lopez, F. J., \& Martsn-Velicia, F. A. (2009). Exploring the impact of individualism and uncertainty avoidance in Web-based electronic learning: An empirical analysis in European higher education. Computers and Education, 52(3), 588-598.

Sun, P. C., Tasi, R. J., Finger, G., Chen, Y. Y., and Yeh, D. (2008). What drives a successful e-Learning? An empirical investigation of the critical factors influencing learner satisfaction. Computer and Education, Vol. 50, pp.1183-1202.

Szajna, B. (1996). Empirical evaluation of the revised technology acceptance model. Management Science, 42(1), 85-92.

Šumak, B., Heričko, M. \& Pušnik, M. (2011). A meta-analysis of e-learning technology acceptance: The role of user types and elearning technology types. Computers in Human Behavior 27, 2067-2077.

T. Pikkarainen, K. Pikkarainen, H. Karjaluoto, and S. Pahnila, "Consumer acceptance of online banking: an extension of the technology acceptance model," Internet research, vol. 14, pp. 224-235, 2004.

Thomas, A., \& Stratton, G. (2006). What we are really doing with ICT in physical

education: A national audit of equipment, use, teacher attitudes, support, and training. British Journal of Educational Technology, 37(4), 617-632.

Thong, J. Y. L., Hong, W., \& Tam, K. Y. (2004). What leads to user acceptance of digital libraries? Com-munications of the ACM, 47(11), 79-83.

Tsai, C-C., and Lin, C. (2004). Taiwanese adolescents ${ }^{\text {ee }}$ perceptions and attitudes regarding the Internet: Exploring gender differences. Adolescence, Vol. 39, pp.725-734. DOI: 12884, 35400012680667.0070.

V. Venkatesh, Creation of favorable user perceptions: exploring the role of intrinsic motivation, MIS Quarterly 23 (2), 1999, pp. 239-260.

V. Venkatesh, "Determinants of perceived ease of use: Integrating control, intrinsic motivation, and emotion into the technology acceptance model," Information systems research, vol. 11, pp. 342-365, 2000.

Venkatesh, V., Speier, C., 2000. Creatingan effective training environment for enhancing telework. International Journal of Human-Computer Studies 52, 991-1005. 
Venkatesh, V., Speier, C., Morris, M.G., 2002. User acceptance enablers in individual decision making about technology: toward an integrated model. Decision Sciences 33, 297-316.

Volman, M. Eck van, E. Heemskerk, I., and Kuiper, E. (2005). New technologies, new differences. Gender and ethnic differences in pupils' use of ICT in primary and secondary education Computers and Education Vol. 45 (1), August 2005 , pp. 35 - 55.

Wu, X. Y., \& Gao, Y. (2011). Applying The Extended Technology Acceptance Model To The Use Of Clickers In Student Learning: Some Evidence From Macroeconomics Classes. American Journal of Business Education, 4(7), 43-50.

Yuh-Ming Cheng, Shi-Jer Lou, Ru-Chu Shih \& Sheng-Huang Kuo, (2013), Investigating elementary school students' technology acceptance by applying digital game-based learning to environmental education. Australasian Journal of Educational Technology, 2013.

Yusoff, Y. M., Muhammad, Z, Zahari, M. S. H., Pasah, E. S., \& Robert, E. (2009). Individual differences, perceived ease of use, and perceived usefulness in the e-library usage. Computer and Information Sci-ence, 2(1), 76-83.

Zhao, Y. (2007). Social studies teachers' perspectives of technology integration. Journal of Technology and Teacher Education, 15(3), 311-333.

Zhu, C., Valcke, M., Schellens, T., and Li, Y. (2009). Chinese students' perceptions of a collaborative e-learning environment and factors affecting their performance: implementing a Flemish e-learning course in a Chinese educational context. Asia Pacific Educ. Rev. 10. pp. 225-235. [Online] accessed at: DOI 10.1007/s12564-009-9021-4 Springer. 